\title{
Program mindful parenting untuk menurunkan kecemasan pada caregiver anak berkebutuhan khusus
}

\author{
Dian Sartika Sari \\ Universitas Mercubuana Yogyakarta \\ *Coresponding Author.dian.s@mercubuana-yogyakarta.ac.id
}

\begin{abstract}
Abstrak : Sebagai pengasuh anak berkebutuhan khusus berhubungan dengan munculnya permasalah fisik dan psikologis pada caregiver. Hal ini memunculkan adanya gejala gejala kecamasan yang tinggi. Tingkat kecemasan yang tinggi bisa berpengaruh terhadap aktivitas sehari hari dan pengasuhan. Hal ini berarti butuh adanya penanganan akan permasalahan ini. Beberapa intervensi cocok dilakukan untuk mengurangi kecemasan. Salah satu Intervensi dengan berbasis mindfulness terbukti dapat membantu memberikan ketenangan dan meningkatkan kebahagiaan. Penelitian ini bertujuan untuk menguji pengaruh program Mindful parenting untuk menurunkan kecemasan pada caregiver anak berkebutuhan khusus. Penelitian ini menggunakan one group pre test dan post test design. Pengukuran kecemasan diukur dengan menggunakan Beck Anxiety Inventory (BAI). Program Mindfulenss parenting terdiri dari 8 sesi program dalam 4 kali pertemuan. Analisis dengan menggunakan uji Wilcoxon rank test menujukkan hasil significant $(\mathrm{Z}=-2,905, \mathrm{p}<0,05)$. Hal ini menunjukkan bahwa hipotesis diterima, program Mindful parenting dapat menurunkan kecemasan pada caregiver anak berkebutuhan khusus
\end{abstract}

Kata Kunci: Mindful parenting. Kecemasan. Caregiver. Anak Berkebutuhan Khusus

\section{Mindful parenting program for decreasing anxiety on caregiver who has children with disability}

\begin{abstract}
Caregiver in children with disability related with physically and psychological problem for example the symptoms of anxieties. They have high score in anxiety and it will be impact in daily activites and parenting. It means that should be solved by intervention. Many interventions can be applied in anxiety. One of them is therapy based on mindfulness has evidence helping them in be calmer dan increase happiness. The aim of this study is to examine the effectiveness of "Mindful parenting" program in decreasing anxiety on caregiver who has child with disability. This study used a one-group pretest-posttest design. "Mindful Parenting" program attended 8 sessions of "Mindful parenting" program in four meetings. Analysis using Wilcoxon signed rank test showed significance result $(\mathrm{Z}=-2,905, \mathrm{p}<0,05)$. It means, hypothesis accepted and can be concluded that there was significant effect of "Mindful parenting" program on decrease anxiety score on caregiver of children with disability.
\end{abstract}

Keywords: Mindful parenting. Anxiety. Caregiver. Children with disability.

\section{PENDAHULUAN}

Mindful parenting merupakan konsep dalam pengasuhan yang menekankan pada proses mengasuh dengan penuh kesadaran (eling). Pengasuhan dengan Mindful parenting merupakan salah satu dari berbagai metode yang mulai banyak disarankan untuk dapat membangun hubungan antara orangtua dan anak yang aman (Kiong, 2015). Mindful parenting terbukti dapat digunakan untuk mengatasi permasalahan pendamping atau orang tua anak berkebutuhan khusus baik untuk mengurangi efek negative (Rinaldi, 2017) atau kesejahteraan psikologis (Rinaldi, 2016).

Anak berkebutuhan khusus adalah anak yang mengalami keterbatasan atau keluarbiasaan, baik fisik, mental-intelektual, sosial, maupun emosional, yang berpengaruh secara signifikan dalam proses pertumbuhan atau perkembangannya dibandingkan dengan anak-anak lain yang seusia dengannya. (Kementrian Pemberdayaan perempuan dan perlindungan anak, 2013). Heward (2003) mendefinisikan ABK sebagai anak dengan karakteristik khusus yang berbeda dengan anak pada umumnya tanpa selalu menunjukkan pada ketidakmampuan mental , emosi atau fisik. Berdasarkan definisi diatas dalam disimpulkan bahwa Anak Berkebutuhan Khusus merupakan individu yang 


\section{J PK (J urnal Pendidikan Khusus), 17 (1), 2021 - 21}

Dian Sartika Sari

memiliki karakteristik fisik, inteletektual dan atau emosi yang berbeda dengan kronologikal anak diusianya.

Di Indonesia, jumlah anak berkebutuhan khusus meningkat setiap tahunnya, Berdasarkan data terbaru, jumlah anak berkebutuhan khusus mencapi 1.544 .184 anak dengan 21,42\% nya berada pada usia 5-18 tahun (Desiningrum, 2016). Daerah Istimewa Yogyakarta menjadi daerah dengan angka penyandang disabilitas yang cukup tinggi. Berdasarkan data Bappeda (2013), provinisi DIY memiliki 3513 anak berkebutuhan khusus dengan angka tertinggi ada di sleman yakni 864 anak berkebutuhan khusus yang tercatat. Gamping merupakan salah satu kecamatan dari kabupaten Sleman. Jumlah Anak Berkebutuhan khusus di wilayah Gamping ini cukup significant. Data Puskesmas Gamping I (2017) menunjukkan bahwa jumlah anak berkebutuhan khusus yang berada di bawah wilayah tanggung jawab Puskesmas Gamping I sekitar 15 orang. Jumlah ini adalah jumlah yang dilaporkan oleh kader jiwa disetiap daerahnya. Menurut psikolog puskesmas Gamping I yang bertugas saat itu, masih ada beberapa anak berkebutuhan khusus yang belum tercatat.

Anak berkebutuhan khusus uumnya akan mengalami ketergantungan dengan orang lain, terutama pada orang tua yang sekaligus menjadi caregiver (Atkinsen \& Coia, 1999). Caregiver adalah individu yang secara umum merawat dan mendukung individu lain dalam kehidupannya (Awad \& Voruganti, 2008). Caregiver ini bisa merupakan orang yang ditugaskan untuk merawat seperti perawat, ataupun pembantu rumah tangga. Namun tidak jarang caregiver pada anak berkebtuuhan khusus ini adalah orang tua dari ABK sendiri.

Caregiver dibagi menjadi dua yaitu caregiver informal dan formal (Dewi, Elvira, \& Budiman, 2013). Caregiver informal adalah seorang individu (anggota keluarga, teman, ataupun tetangga) yang memberikan perawatan tanpa dibayar, paruh waktu atau sepanjang waktu, tinggal bersama atau terpisah dengan orang yang dirawat, sedangkan caregiver formal merupakan bagian dari sistem pelayanan, baik dibayar ataupun sukarela (Dewi, Elvira, \& Budiman, 2013). Caregiver yang dimaksud dalam penelitian ini adalah Caregiver informal khususnya orang tua.

Seorang caregiver memiliki tugas untuk memberikan perawatan ketika penderita tidak dapat memenuhi kebutuhannya sendiri (Stuart, 2009). Selain itu, seorang caregiver (pendamping) memerlukan pengetahuan, kemauan, pengabdian, dan kesabaran. Caregiver memiliki beban perawatan yang kompleks dan menantang. Banyaknya beban yang dihadapi caregiver dapat menyebabkan atau mempengaruhi kondisi fisik, psikologis, sosial dan ekonomi. Selain dampak emosional, psikologis, fisik dan ekonomi, beban perawatan seorang caregiver secara halus juga melibatkan rasa malu, perasaan bersalah dan menyalahkan diri sendiri (Awad \& Voruganti, 2008).

Berdasarkan wawancara dengan caregiver yang juga orang tua anak berkebutuhan khusus mereka mengeluhkan beban yang mereka tanggung, beberapa dari mereka mengalami psikosomatis, dan juga kecemasan yang tinggi. Berdasarkan pengukuran kecemasan awal dengan Beck Anxiety Inventory (BAI), 15 caregiver ABK berada dalam kecemasan yang tinggi. Skor nya berkisar antara 3550 dimana termasuk dalam kategori tinggi. BAI sendiri mengukur mengenai tingkat kecemasan yang diuraikan berdasarkan gejala-gejala kecemasan. Namun, fokus penananganan pada caregiver masih belum difokuskan. Penelitian dan penanganan terkait banyak berfokus pada anak berkebutuhan khususnya. Oleh sebab itu, peneliti merasa perlu utnuk meneliti terkait dengan intervensi yang dapat diberikan pada caregiver Anak Berkebutuhan Khusus (ABK).

Kartini Kartono (1989: 120) menjelaskan bahwa cemas adalah bentuk ketidakberanian ditambah kerisauan terhadap hal-hal yang tidak jelas. Demikian juga, Sarlito Wirawan Sarwono (2012: 251) menjelaskan kecemasan merupakan takut yang tidak jelas objeknya dan tidak jelas pula alasannya. Berdasarkan hasil wawancara beban yang dialami caregiver ABK cukup banyak, mulai dari stigma masyarakat, bagaimana memanage ekspektasi dari keluarga, dirinya dan juga ABK, hingga bagaimana masa depan dari ABK nantinya. Sebagian mengkhawatirkan jika nanti mereka sudah tidak bisa merawat ABK lagi, lalu siapa yang akan merawatnya dimasa depan, bagaimana ABK ini akan menjalani kehidupannya dimasa depan. Pikiran-pikiran pada hal yang belum terjadi dan belum jelas ini memunculkan reaksi kecemasan pada caregiver ABK yang berakibat pada tingkat kecemasan yang tinggi.

Salah satu intervensi yang banyak digunakan untuk mengatasi kecemasan adalah Cognitive behavior therapy (CBT). Cognitive Behavior Therapy (CBT) merupakan suatu bentuk psikoterapi yang bertujuan untuk menangani perilaku maladaptif dan mereduksi penderitaan psikologis, dengan cara mengubah proses kognitif individu (Grebb, Kaplan, dan Sadock, 2010). Tujuan dasar dari CBT 


\title{
J PK (J urnal Pendidikan Khusus), 17 (1), 2021 - 22
}

\author{
Dian Sartika Sari
}

adalah untuk mengajarkan kepada klien bagaimana untuk mengubah pemikiran maladaptif serta disfungsi emosi dan perilaku menjadi sesuatu yang sehat (Corey, 2013). Pelaksanaan terapi CBT individu dengan kelompok memiliki perbedaan. Pada CBT kelompok meningkatkan keterlibatan anggota kelompok secara berkala dalam menentukan tujuan, rencana, pembuatan keputusan, dan menciptakan hubungan yang mutualisme (saling membantu satu sama lain) (Corey, 2012).

Saat ini terapi perilaku kognitif sudah banyak berkembang dan dimodifikasi. Terapi perilaku generasi saat ini banyak menekankan pada mindfulness, acceptance, the therapeutic relationship, spirituality, values, makna dan tujuan hidup serta neditasi (Linehan dalam Coray 2013). Pendekatanpendekatan baru ini memberi dampak pada terapi perilaku, terutama dalam mengobati masalah klinis yang lebih sulit (Guevremont dalam Coray 2013). Salah satu modifikasi terapi kognitif perilaku adalah terapi kognitif perilaku yang berbasis mindfulness atau lebih dikenal dengan midnfulness based on cognitive therapy (MBCT). Midnfulness based on cognitive therapy (MBCT). dikembangkan kemudian dengan difokuskan untuk mereduksi stress dan kecemasan ini dikenal dengan mindfulness based stres model (MBSR) yang dikembangkan oleh Rebecca (2009).

Mindfulness Based Stress Reduction (MBSR) adalah intervensi yang efektif untuk mengurangi stres dan meningkatkan kesejahteraan psikologis bagi orang tua atau caregiver anak anak yang mengalami keterbelakangan mental. (Bazano, Alicia et all 2013). Rinaldi (2017) mengemukakan bahwa program Mindful parenting dapat menurunkan afek negatif dari ibu dengan anak keterlebakangan mental. Ibu yang membawa mindfulness kedalam pendampingan atau pengasuhann merupakan salah satu aplikasi dari Mindful parenting. Pengasuhan disini pada umumnya terkait dengan pola asuh orang tua dan anak dimana secara spesifik orang tua disini juga berperan sebagai caregiver dari anak berkebutuhan khusus.

Berdasarkan latar belakang diatas, peneliti ingin melihat bagaimana program Mindful parenting dapat mempengaruhi tingkat kecemasan dari caregiver anak berkebutuhan khusus dimana yang dimaksud caregiver disini secara spesifik adalah orang tua anak dari anak berkebutuhan khusus yang bertanggung jawab merawat keseharian anak. Pernyataan ini diperkuat dengan Ariesta (2016) yang menyebutkan bahwa orang tua anak berkebutuhna khusus memiliki kecemasan akan kemampuan anak berkebutuhan khusus dalam menulis, membaca, menyelesaikan sekolah dengan baik, berinteraksi dengan teman sekolah, memahami pelajaran sekolah serta tidak akan ada tempat bekerja yang akan menerima.

\section{METODE}

Desain dari penelitian menggunakan "the one group pretest- post test design" (Shadish, Cook, \& Campbell, 2002) dengan pendekatan kuantitatif. Peneliti hanya menggunakan kelompok eksperimen yaitu kelompok yang menerima intervensi program Mindful parenting. Hal ini dikarenakan terbatasnya subjek penelitian yang dapat mengikuti seluruh rangkaian kegiatan pelatihan

Sasaran dari penelitian ini adalah caregiver yang merupakan orang tua dari anak berkebutuhan khusus. Penelitian ini dilakukan pada 8 orang. Adapun syarat sebagai subjek dalam penelitian ini adalah (1) Caregiver dari anak berkebutuhan khusus yang sekaligus menjadi orang tua anak. Hal yang dimaksud disini adalah orang tua menjadi pengasuh utama anak dan tinggal bersama dengan anak berkebutuhan khusus. Orang tua bertanggung jawab utama untuk merawat anak berkebutuhan khusus dan tidak meminta perawat untuk membantu merawatnya dalam sehari hari. Oleh sebab itu dapat dikatakan caregiver. (2) mampu melakukan mobilisasi secara memadai untuk bergabung dalam proses intervensi, (3) mampu berbahasa Indonesia dengan baik secara lisan dan tertulis. Teknik sampling dilakukan dengan purposive sampling, dimana subjek yang dipilih adalah subjek yang memenuhi kriteria dari yang telah ditetapkan

Variabel bebas dalam penelitian ini berupa program "Mindful parenting", yaitu intervensi berbasis mindfulness yang diaplikasikan dalam pengasuhan. Program dilaksanakan dalam empat kali pertemuan dengan durasi sekitar 180 menit selama dua minggu. Sedangkan yang menjadi variabel tergantung adalah kecemasan.

Instrumen dalam penelitian ini adalah (1) Skala kecemasan dengan menggunakan Back Anxiety inventory (BAI), (2) Buku Harian, (3) Lembar Observasi. Skala kecemasan dengan Back Anxiety inventory (BAI) memiliki validitas $(\mathrm{r}=0,48)$ dan reabilitas $(0,75)$. Buku harian disusun dengan tujuan untuk melihat perkembangan partisipan setiap harinya selama mengikuti program. Buku ini berisi pencatatan latihan pada saat di luar proses pelatihan (tugas rumah). 


\title{
J PK (J urnal Pendidikan Khusus), 17 (1), 2021 - 23
}

\author{
Dian Sartika Sari
}

Analisis data pada penelitian ini dilakukan dengan menginput data menggunakan SPSS kemudian dilakukan uji analisis data dengan SPSS menggunakan uji Wilcoxon Signed Rank Test. Uji Wilcoxon merupakan metode analisis statistik non parametrik dengan membandingkan dua sampel yang berhubungan (Corder \& Foreman, 2009).

\section{HASIL DAN PEMBAHASAN}

Hasil cek manipulasi dengan dengan menggunakan Wilcoxon signed rank-test diperoleh nilai $\mathrm{Z}=-2,760$ dengan $\mathrm{p}=0,004$. Hal ini mengindikasikan bahwa terdapat perbedaan keadaan atau ketrampilan Mindful parenting antara sebelum dan sesudah diberikannya program "Mindful parenting". Hal ini sejalan dengan Wilcoxon signed ranktest terhadap kecemasan yang menunjukkan $(\mathrm{Z}=-2,905, \mathrm{p}<0,05)$ pada sebelum dan sesudah diberikan perlakuan. Hal ini menunjukkan bahwa hipotesis penelitian ini diterima, terdapat penurunan kecemasan yang significant sebelum dan sesudah pemberian intervensi (program Mindful parenting). Penurunan ini tidak hanya terlihat pada hasil pengujian statistik namun juga pada angka kecemasan yang menunjukkan penurunan relatif dari berat menuju ringan atau sedang.

Hasil penelitian ini menunjukkan bahwa program "Mindful parenting” memberikan manfaat pada caregiver yang juga sebagai orang tua dari anak berkebutuhan khusus. Caregiver mengalami epnurunan kecemasan. Hal ini sesuai dengan penelitian Bogels (2010) bahwa Mindful parenting dapat membuat pengasuh lebih tenang dalam menghadapi perilaku negatif pasien / anak (Bogels, Susan 2010).

Kecemasan salah satunya menunjukkan manifestasi dari beban dan pikiran serta kekhawatiran di masa depan. Suasana hati yang tidak menyenangkan, seperti tertekan, merasa bersalah, atau marah. Tingginya afek negatif yang terjadi pada individu membuat individu merasakan emosi negatif (Diener, 2000). Hal ini berbeda dengan individu yang berada pada kondisi mindfulness. Individu yang mindfulness memiliki kemampuan yang lebih besar dalam mengendalikan pikiran, emosi dan pengalaman (Baer, 2003). Serangkaian program Mindful parenting ini akan mengajarkan caregiver untuk dapat mengendalikan pikiran terutama akan kekhawatirannya dimasa depan terkait dengan perkembangan ABK. Kemampuan mengendalikan pikiran ini membuat individu mengalami penurunan tingkat kecemasan.

Mindful parenting ini memberikan ketrampilan pada caregiver untuk mengasuh anak berkebutuhan khusus dengan penuh perhatian, tidak reaktif, dan menerima seluruh pengalaman pengasuhan tanpa memberikan penilaian (Duncan, 2009). Pemberian perhatian yang penuh dan tidak reaktif ini akan membuat caregiver merasa lebih tenang dan mampu menerima pengalaman yang tidak sesuai dengan harapannya. Hasil dalam penelitian ini sejalan dengan teori tersebut, hasilnya menunjukkan bahwa caregiver menjadi lebih mampu menerima pengalaman pengasuhan tanpa memberikan penilaian-penilaian terhadap kondisi anak ataupun lingkungan sekitar. Caregiver juga menunjukkan sikap yang tidak reaktif terhadap kondisi pengasuhan yang banyak tidak sesuai dengan harapan caregiver pada awalnya.

Ketika individu melakukan praktek mindfulness, individu akan memiliki kesadaran yang lebih terhadap suatu pengalaman. Individu yang lebih menyadari peristiwa akan memiliki kesadaran yang tinggi dan cenderung memiliki kondisi emosional yang lebih stabil. Mindfulness dapat memengaruhi dalam menerima emosi dengan lebih tepat dan dapat meregulasi emosi dengan efektif sehingga dapat meningkatkan kepuasan hidupnya (Wang \& Kong, 2013). Fredrickson (dalam Brown, 2015) menjelaskan bahwa kondisi emosional yang positif dapat meningkatkan kemampuan dalam memproses dan menyimpan informasi baru, dan untuk membuat pola pikiran sehingga individu menjadi lebih positif dan kreatif. Pola seperti ini akan mengurangi symptom-symptom kecemasan pada diri individu.

Tahapan yang dilakukan pada program Mindful parenting yakni terkait dengan mengenali sumber stress dan emosi, memahami sensasi tubuh, merespon stress, memahami dan menerima keterbatasan. Dengan tahapan ini caregiver akan diajak untuk memahami keadaan stress yang dialami nya serta emosi yang muncul, mengenali sensasi tubuh yang dirasakan dan bagaimana meresponnya dengan adaptif. Pada akhirnya caregiver akan menerima keterbatasan diri dalam pengasuhan. Hal ini akan membuat caregiver mengurangi ketegangan pada harapannya akan pengasuhan dan anak sehingga pikiran negatif akan hal hal yang belum terjadi dapat direspon dan 


\section{J PK (J urnal Pendidikan Khusus), 17 (1), 2021 - 24}

Dian Sartika Sari

diminimalisir dengan sehat sehingga kecemasannya akan menurun. Hal ini sejalan dengan penelitian Rinaldi (2016).

\section{SIMPULAN}

Secara keseluruhan dapat disimpulkan bahwa program “Mindful parenting” dapat menurunkan kecemasan pada caregiver yang juga sebagai orang tua anak berkebutuhan khusus. Kegiatan mindfulness dimana fokus dari program ini adalah bagaimana membawa caregiver berfokus pada keadaan saat ini dan terlibat pada pengalaman saat ini sehingga mengurangi pemikiran-pemikiran negatif yang belum terjadi yang menjadi pemicu dari timbulnya kecemasan. Secara lebih rinci, hal-hal yang diberikan dalam mindful parenting adalah mengenali emosi, memahami sensasi tubuh, merespon stress, memahami dan menerima keterbatasan.

\section{DAFTAR PUSTAKA}

Atkinsen, J., \& Coia, D. (1999). Families coping with schizophrenia : A practitioner's guide to family groups.

Ariesta, A. (2016). Kecemasan orangtua terhadap karir anak berkebutuhan khusus. E-Journal Bimbingan dan Konseling, 5(4), 50-61.

Awad, A. G., \& Voruganti, L. N. (2008). The Burden of Schizophrenia on Caregivers: A Review. Pharmaco Economics , 62-149.

Baer, R. A. (2003). Mindfulness training as a clinical intervention: A conceptual and empirical review. Clinical Psychology: Science and Practice, 10, 125-143.

Bappeda.2013. Data Anak Berkebutuhan Khusus Wilayah Provinsi Yogyakarta.

Bazzano, Allicia. 2013. Mindfulness Based Stress Reduction (MBSR) for Parents and Caregivers of Individuals with Developmental Disabilities: A Community-Based Approach. Newyork. Springer Science+Business Media.

Bogels, S. Restifo, K. 2014. Introduction to Mindfullness Parenting: A Guide for Mental Health Practitioners. Newyork. Springer Science Business Media.

Brown, K. W. (2015). Mindfulness Training to Enhance Positive Functioning. Dalam Brown, K. W., Creswell, J. D., \& Ryan, R. M. Handbook of Mindfulness: Theory, Research, and Practice. New York: The Guilford Press

Bogels, Susan. 2010. Mindful Parenting in Mental Health Care. Newyork. Springer Science Bussiness Media. Vol.1: 107-120

Cane, Rebecca. 2009. Mindfulness Based Cognitive Therapy. London. Roudledge

Corey, G. (2013). Theory and Practice of Group Counseling Eight Edition. California : Brooks. Cole Cengage Learning

Corder, G. W., \& Foreman, D. L. (2009). Nonparametric statistics for non- statisticians: A step by step approach. Canada: John Wiley \& Sons, Inc

Diener, E. (2000). Subjective well- being: The science of happiness and a proposal for a national index. American Psychologist, 55(1), 34-43.

Desiningrum, Deine. 2016. Psikologi Anak Berkebutuhan Khusus. Psikosain.Yogyakarta

Dewi, S., Elvira, S. D., \& Budiman, R. (2013). Gambaran Kebutuhan Hidup Penyandang Skizofrenia. Kebutuhan Hidup Penyandang Skizofrenia , 84-90

Duncen, L. G., Coatsworth, J. D., \& Greenberg, M. I. (2009). A Model of Mindful Parenting: Implications for Parent-Child. Clinical Child and Family Psychology Review, 255-270

Heward, W.L. 2013. Exceptional Children in education to special Education. New Jersey. Merrill. Prentice Hall.

Kartini Kartono. (1989). Hygiene Mental dan Kesehatan Mental dalam Islam. Bandung: Mandar Maju. 
Kementrian Pemberdayaan perempuan dan perlindungan anak. 2013. Penanganan Anak Berkebutuhan Khusus. Jakarta

Kiong, M. (2015). Mindfull Parenting.pdf. Jakarta: Kementerian Pendidikan dan Kebudayaan.

Rinaldi, Martha. 2016. Program “Program Mindful Parenting” untuk meningkatkan kesejahteraan psikologis pada ibu yang memiliki anak retardasi mental. Gadjah Mada Journal of Professional Psychology. Volume 2, No. 2, 2016: 100-115 ISSN: 2407-7801

Rinaldi, Martha. 2017. Program "Program Mindful Parenting” untuk menurunkan afek nagetif pada ibu yang memiliki anak retardasi mental. Yogyakarta. Insight Vol 19 No 2. ISSN: 1693-2552

Sarlito Wirawan Sarwono. (2012). Pengantar Psikologi Umum. Jakarta: Rajawali Pers.

Scharf, R. J., Maphula, A., Pullen, P. C., Shrestha, R., Matherne, G. P., Roshan, R., \& Koshy, B. 2017. Global Disability: Empowering Children of all Abilities. Pediatric Clinics of North America, 64(4), 769-784.

Shadish, W.R., Cook, T. D., \& Campbell, D. T. (2002). Experimental and Quasi- Experimental Designs for Generalized Causal Inference. Boston, MA, US: Houghton, Mifflin and Company.

Wang, Y., \& Kong, F. (2013). The Role of Emotional Intelligence in the Impact of Mindfulness on Life Satisfaction and Mental Distress. Social Indicators Research, 116 (3), 843 - 852. https://doi.org/10.1007/s11205- 013-0327-6.

WHO. 2011. World Report On Disability. Geneva: World Health Organization.

\section{PROFIL SINGKAT}

Penulis bernama Dian Sartika Sari, lahir di Yogyakarta, 23 Februari 1992; telah selesai menempuh Pendidikan Magister Profesi Klinis di Universitas Gadjah Mada pada tahun 2020. Pekerjaan saat ini mengajar (sebagai dosen tetap) di Universitas Mercubuana Yogyakarta pada Fakultas Psikologi. 